\title{
Cultivation with Management of College Administration
}

\author{
Zhonghai Qiu ${ }^{1,}$, Xiuli Guan ${ }^{2, b}$ \\ 1, 2 North China Institute of Science and Technology Sanhe, Hebei, China, 065201 \\ aemail: aqiuzhonghai@yeah.net, b879630920@qq.com
}

Keywords: college; administration; cultivation with management

\begin{abstract}
College management is implemented by administrators. As the center and backbone of college management team, the administrators play an important role in the process of carrying out the mission of management. Based upon the analysis of the implementation and existing problems in cultivation with management of administrative departments, this paper puts forward some effective ways to achieve the optimization of management.
\end{abstract}

\section{Introduction}

The official document On Further Strengthening and Improving Ideological and Political Education issued by CPC Central Committee and the State Council advances higher requirements for college administration and clearly points out that administrators should combine education with management in carrying out their mission. From this perspective, cultivation with management serves not only as an important part of college education, but also a significant way of strengthening and improving the ideological and political education of college students in the new period. As the implementer and organizer of policies and decisions made by the Party committees and leading administrative team, the administration serves a vital connecting link between the leading officials and the teaching staffs. Hence, each administrative department should combine its job duties with the characteristics of the section, center on the idea of cultivation with management, innovate their working concepts, elevate their level of management, set up a favorable environment of cultivation with management, and carry out work in a solid and effective way.

\section{The Connotation of Cultivation with Management}

Cultivation with management can be defined as a process in which the administration and administrators impose a series of regulations, norms, and political and ideological education on the students through a variety of ways and intermediate links in order to achieve the goal of moral education of the school. Cultivation with management and classroom teaching exist side by side and complement each other since the working style, thinking style and moral status of the administrators have a direct impact on students while they are carrying out the management mission. From the perspective of managing process, the quality and image of administrative staffs could have a great impact on students. What's more, colleges achieve the goal of cultivating students through perfect management system and proper management measures. From the perspective of management mode, management system, regulations and measures serve as the carriers of cultivation, and could have a regular, normative, equal, and restrictive influence on students, which enables colleges to gain the unity of ideological education and code of conduct, ideals and reality. From the perspective of management sphere, as the support of whole operation system, management couldn't vary with the change of any administrator, and it has the global and relative stability. The management covers not only all the students, but also administrative staffs, teachers and other staffs of the school. Therefore, the larger sphere the management relates, the greater function it requires. At the same time, thanks to its role and function, cultivation with management plays a major role in guiding and promoting development of cultivation with education and cultivation with service. From the perspective of management function, cultivation with management focuses on the discipline and restriction imposed on the students, while cultivation with education and cultivation with service emphasize the gradual influence on the students. Nevertheless, every aspect of the school reform could be pushed forward through the implementation of related regulations of administration. 


\section{Existing Problems in Cultivation with Management}

\subsection{Lack of Sufficient Awareness}

In college, there are a large proportion of administrative staffs short of awareness of management, who put more emphasis on teaching and research but neglect the significance of management, and don't realize the fact that the optimization of management helps to create a favorable environment for education. In recent years, with the constant enlargement of college enrollment, teachers as well as students have increased dramatically, so most colleges have invested much energy and financial resources in improving the infrastructure construction and recruiting the high-level talents. In contrast, they have ignored the management construction, which have undoubtedly to a great extent affected the school-running efficiency and the construction of favorable education atmosphere.

\subsection{Lack of Complete Management System}

For most colleges, the management system needs to keep pace with the times. Being outdated or unestablished, only a few rules are unrestrained by some other rules and can be independently carried out for many administrative departments. The current situation of management system can be reflected from the following problems related to management rules and regulations of colleges. Few rules and regulations are normative; some are difficult to be implemented since they are contradictory with some policies of the superior organizations; some are too vague and obscure to implement because most of them have been put forward without being deeply researched or fully discussed; some lack the incentive measures for encouragement and competition helping to establish a better atmosphere of "everybody participates, everybody contributes" to make full potential of vast majority of teaching stuffs.

\subsection{Separating Management from Education}

Some administrators lack for awareness of cultivation with management and don't have a sufficient understanding about it. They misunderstand that the duty of educating students belongs to the teachers, class advisers and instructors, and it has nothing to do with them. Thus, without joint forces, the management of college students becomes the main concern of a small proportion of administrative staffs. Some administrative staffs only care about are the documents or commands from the higher authorities, and they have no intention of doing research or accepting suggestion from others when handling students' affairs, which causes serious conflict between the students and them. Students even distrust them because they don't hold firm to the principles of justice, fairness and openness in dealing with some affairs closely related to students' interests, such as discipline, award, employment, joining the Party and the like.

\subsection{Low Quality of Administrators}

In recent years, with a large number of high-degree talents joining in, the structure of age, educational background, and knowledge of management team have been largely improved. So it's not uncommon that most directors of a college are professors, and some section-level administrators are doctors or masters. The previous time when the family members of school leaders could easily come aboard has gone. However, there are still some problems in the management team. Some of administrators are outdated, and they lack for the courage and spirit to renew their knowledge and improve their way of thinking; some administrative departments are overstaffed, and some senior staffs hold the belief that there is no difference between doing it or not, doing more or less, and doing well or badly. Some of the management personnel haven't received any pre-job training or been specially cultivated. With simple knowledge structure, they are short of modern management knowledge and experience.

\section{Ways of Cultivation with Management}

\subsection{Establishing and Improving Management System}

Mechanism for incentive, supervision and restriction should be set up to benefit the development of a college. Above all, management rules shouldn't run counter to some policies and 
regulations of superior organizations. Besides, before putting forward some rules, management departments should do a deep research and detailed analysis to ensure that every rule suits the school and is proper and reasonable. Then, administrative departments should coordinate with each other and agree on the established regulations. Otherwise, students will have no idea about which rule is right and should be followed. What's more, administrative departments should take the stability and consistency of a policy into consideration because constant changing of any rule could affect the authority of a school. Finally, the administrators must stick to principles. Once a regulation is put into force, it must be observed and strictly enforced and violators must be brought to justice. Meanwhile, in the process of carrying out the rules, they should steadily take on the task of educating students in a proper way to create a favorable atmosphere for cultivation with management and guide students to bear regulations and rules in mind and conduct themselves.

\subsection{Improving the Quality of Administrators}

Confucius said: If the ruler is personally upright, all will go well even though he does not give orders. But if he is not personally upright, even though he gives orders, they will not be obeyed. In colleges, the administrators play a decisive role whether the whole education activity could succeed or not, since their quality has a direct impact on the quality, the level, and the effectiveness of the education. The administrators' self-image and behavior is a living textbook for moral education, and their words and deeds will be imitated or patterned by the students. Through them, the students could experience the concepts of management, the academic approaches, professional dedication of the school, and probably regard them as practical examples giving them some reference and enlightenment for learning, living, and walking from school to society. Therefore, the administrative staffs should be strict with and discipline themselves, impartial, influencing and educating the students by deeds rather than by words.

\subsection{Standardizing the Order of Handling Affairs}

Orderly management requires that the school administrators have clear goals, systematic and long-term development planning with an eye to the present and future. A temporary working scheme is also a relative complete plan going around the overall plan, which shouldn't only raise a list of problems without any intention to solve the problems. The variety of rules, regulation, and management measures of a school should be guided by scientific theories and the coming about of every one of them should be based on scientific theories and practice, and supported by feasible measures. As administrators, they should make a macro in-depth research on their management work, with which to guide their daily work practice, from perceptual to rational.

\subsection{Creating a Favorable Atmosphere for Education}

As the Chinese old saying goes, If you have been staying in a room full of fragrant orchids for a long time, gradually you won't smell the aromatic odor because you are getting used to it. That is, the environment plays an important role in the process of students' growing-up. The administrative departments should lay emphasis on combining institutionalized management with human-based management, enabling good supervision gradually influence the students and set a seal on their minds. Only by adopting student-oriented management, can they gain mutual respect with students, better coordinate the relationship between management and education, promote the efficiency of cultivation with management. Meanwhile, all administrative departments need harmoniously cooperate with each other, make management work better facilitate and serve students, and enable them to accept being supervised under a favorable atmosphere.

\section{Conclusion}

Persevering in cultivation with management in college is the most crucial step in creating an atmosphere of education, improving the environment of education, and realizing the goal of education. Strengthen management, organize scientifically, allocate properly, command elaborately, coordinate the development, and elevate the level of management constantly, are not only specific routine work but also serving as a kind of supporting of the running and developing of other works. College management is implemented by administrators. As the center and backbone of college management team, the administrators play an important role in the process of carrying out the 
mission of management. Each administrative department should combine its job duties with the characteristics of the section, center on the idea of cultivation with management, innovate their working concepts, elevate their level of management, set up a favorable environment of cultivation with management, and carry out work steadily and effectively.

\section{References}

[1] Zihua Ouyang, Shallow Talk of Invisible Educational Function Working in College Office, Modern Education BBS, 2007(10).

[2] Liu Mei, General Theory of College Management Education, Journal of Yancheng Institute of Technology(Social Science Edition) 2005(4).

[3] Li Jing, Research of Effective Ways of College Party Organization Management Education, Journal of NEDU $〔 J] 27(3)$.

[4] Kang Cuiping and Guo Jie. Present Stuation and the Trend of College Student to Participate in College Management[J] Education Research in Liaoning, 2007(3):21-24.

[5] Huang Xunmei. General Discussion of College Management Education[J].Economic Management in East China1999(6):109-110.

[6] Li Huiyuan. New Explore of College Management Education[J].Journal of North China University of Water Conservancy and Electric Power2002,18(2):95-96. 